Data Article

\title{
Dataset from 55 experts engaged in nature conservation in Mozambique
}

\author{
Aires Afonso Mbanze a, b, c, *, Natasha Sofia Ribeiro ${ }^{\mathrm{d}}$, \\ Carina Vieira da Silva ${ }^{\text {b, e }}$, José Lima Santos ${ }^{c}$

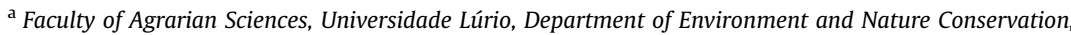 \\ Niassa Province, Campus Universitários de Unango, Sanga District, Mozambique \\ ${ }^{\mathrm{b}}$ Nova School of Business and Economics, Universidade Nova de Lisboa, Campus de Carcavelos, Rua da \\ Holanda, P.O. Box., 2775-405, Lisbon, Portugal \\ ${ }^{\mathrm{c}}$ Centre for Forest Studies (CEF), Instituto Superior de Agronomia (ISA), Universidade de Lisboa, Tapada da \\ Ajuda, P.O. Box, 1349-017, Lisbon, Portugal \\ d Eduardo Mondlane University, Faculty of Agronomy and Forest Engineering, Av. J. Nyerere 3453/Campus \\ Universitário Principal, Maputo, Mozambique \\ ${ }^{\mathrm{e}}$ MARE - Marine and Environmental Sciences Centre, Faculdade de Ciências, Universidade de Lisboa, Av. \\ Nossa Sra do Cabo 939, 2750-374, Cascais, Portugal
}

\section{A R T I C L E I N F O}

\section{Article history:}

Received 27 November 2019

Received in revised form 4 December 2019

Accepted 23 December 2019

Available online 3 January 2020

Keywords:

Conservation experts

Developing countries

Perceived views and Niassa National Reserve

\begin{abstract}
A B S T R A C T
The data of this article is related to the original article entitled " $\mathrm{An}$ expert-based approach to assess the potential for local people engagement in nature conservation: The case study of the Niassa National Reserve in Mozambique" [1], published in Journal for Nature Conservation. The dataset is from an online and selfadministrated survey with 55 experts aware of conservation policies and incentives under implementation in the Niassa National Reserve (NNR), the largest protected area in the country and thirdlargest in Africa. The survey included four sections of both compulsory and non-compulsory questions, mostly in closedended Likert-scale. In the first section, experts were asked about the main practices that threaten biodiversity conservation in the NNR, the actors who are directly and indirectly responsible for each practice, and the reasons for local people's involvement with those practices. The second section was about the effectiveness and limitations of the current compensation measures to engage local residents with conservation-friendly practices. In the third section, respondents were asked to select new measures to
\end{abstract}

DOI of original article: https://doi.org/10.1016/j.jnc.2019.125759.

* Corresponding author. Faculty of Agrarian Sciences, Universidade Lúrio, Department of Environment and Nature Conservation, Niassa Province, Campus Universitários de Unango, Sanga District, Mozambique.

E-mail address: ambanze@unilurio.ac.mz (A.A. Mbanze). 
enhance the current conservation status and engage local people more effectively in conservation. The last section was about the socio-economic profile of respondents. The survey was conducted from June to September 2017. The paper includes the survey itself, raw data in an Excel spreadsheet, descriptive analysis, crosstabulation and Post Hoc cellwise tests (goodness of fit). Data are provided for public use and can serve as a benchmark for collaboration in order to conduct more comprehensive research, comparative analysis as well as panel data can be derived. This data can also have applications in other fields such as mathematics, statistics, and computation.

(1) 2020 The Authors. Published by Elsevier Inc. This is an open access article under the CC BY license (http://creativecommons. org/licenses/by/4.0/).

Specifications Table

\section{Subject area}

More specific subject area

Type of data

How data was acquired

Data format

Experimental factors

Experimental features

Data source location

Data accessibility

Related research article
Environmental science

Management, Monitoring, Policy, and Law

Excel files, table and online questionnaires

Online and self-administration survey

Raw, filtered and analysed

Respondents were selected based on education, number of visits, time spent while visiting, the objective of the visit and years of experience in conservation

Online and self-administration survey was conducted to 55 experts engaged in conservation in Mozambique, from June to September 2017

Mozambique countrywide (mainly in Maputo city, Lichinga city, Mecula, Marrupa and Mavago districts in the Niassa Province, closer to the Niassa National Reserve)

Data are available with this article

Author's name: Aires Afonso Mbanze, Natasha Sofia Ribeiro, Carina Vieira da Silva and José Lima Santos

Title: "An expert-based approach to assess the potential for local people engagement in nature conservation: The case study of the Niassa National Reserve in Mozambique"

Journal: Journal for Nature Conservation

DOI: https://doi.org/10.1016/j.jnc.2019.125759

\footnotetext{
Value of the data

- Data can be used for site comparison among different conservation areas;

- Data can serve as a benchmark for further collaborative research;

- The questionnaire can be replicable and improved in future studies;

- Data can be analysed on different ways to come up with other possible scenarios to advise decision-makers and conservation experts on how to improve conservation of protected areas in developing countries;

- Data can also be used in other fields, including statistics and computer sciences.
}

\section{Data}

The dataset of this article is related to experts' views about conservation policies and incentives implemented at Niassa National Reserve (NNR). The questionnaire used to generate the dataset is presented in Appendix A. Raw Excel dataset is online available on mendely data (https://data. mendeley.com/datasets). The detailed information regarding the profile of respondents is presented in Table 1. Table 2 presents more detailed information about the socio-demographic information of respondents. Table 3 presents the different rating scales used for each major themes; Tables 4-8 are the post-hoc cellwise comparisons between major themes with meaningful explanation; and Table 9 
Table 1

Organizations from which the surveyed respondents were selected.

\begin{tabular}{ll}
\hline Organization & Number of respondents (\%) \\
\hline Conservation NGOs & $9(16)$ \\
Private sector (concessionaries of Hunting Blocks) & $4(7)$ \\
Governmental institution & $5(9)$ \\
National Ministry of Land, Environment and Development & $19(35)$ \\
Provincial and district environment and conservation related institution & $10(18)$ \\
Academic Institutions & $2(4)$ \\
Universities and Technical Institutes & $6(11)$ \\
Research institutions & $55(100)$ \\
Others & \\
Total & \\
\hline
\end{tabular}

Table 2

Socio-demographic information of respondents.

\begin{tabular}{|c|c|c|c|}
\hline $\mathrm{N}^{\mathrm{O}}$ & Variables & Frequency & Percentage (\%) \\
\hline \multirow[t]{3}{*}{1} & Gender & & \\
\hline & Male & 43 & 78.2 \\
\hline & Female & 12 & 21.8 \\
\hline \multirow[t]{4}{*}{2} & Education & & \\
\hline & Professional Education (basic or secondary) & 15 & 27.3 \\
\hline & Upper Secondary School & 6 & 10.9 \\
\hline & Higher Education & 34 & 61.8 \\
\hline \multirow[t]{5}{*}{3} & Major Field & & \\
\hline & Agriculture & 32 & 58.2 \\
\hline & Biology & 4 & 7.3 \\
\hline & Social Sciences & 9 & 16.4 \\
\hline & Others & 10 & 18.2 \\
\hline \multirow[t]{7}{*}{4} & How long have you stayed there? & & \\
\hline & Any time & 12 & 21.8 \\
\hline & less than a month & 13 & 23.64 \\
\hline & 1-4 Months & 10 & 18.2 \\
\hline & $5-8$ months & 2 & 3.6 \\
\hline & 8-12 months & 3 & 5.5 \\
\hline & $>12$ & 15 & 27.3 \\
\hline \multirow[t]{7}{*}{5} & The main objective of your trip & & \\
\hline & Working & 29 & 52.7 \\
\hline & Research & 11 & 20 \\
\hline & Just passing through & 1 & 1.8 \\
\hline & Tourism & 4 & 7.3 \\
\hline & Visit & 1 & 1.8 \\
\hline & Others & 9 & 16.4 \\
\hline \multirow[t]{5}{*}{6} & Years of experience in conservation & & \\
\hline & $1-2$ & 16 & 31.37 \\
\hline & $3-5$ & 19 & 37.25 \\
\hline & $6-10$ & 12 & 23.53 \\
\hline & $>10$ & 4 & 7.84 \\
\hline
\end{tabular}

presents a post-hoc cellwise test between experts' level of education and the level of improvement of different attributes after implementation of new proposed measures.

\section{Experimental design, materials and methods}

Data were obtained from experts highly involved in the design and implementation of conservation measures in Mozambique. The criteria used to select the experts were the following: (1) have worked 
Table 3

Rating scale coded for the four major themes that experts were requested to answer to.

\begin{tabular}{|c|c|c|c|}
\hline $\mathrm{N}^{\mathrm{o}}$ & Major themes & Rating scale & Source \\
\hline Q.1 & $\begin{array}{l}\text { Identify the degree of threat each of the existing } \\
\text { problems in the NNR represents for } \\
\text { conservation }\end{array}$ & $\begin{array}{l}0=\text { very little, } 1=\text { little, } 2=\text { moderate, } 3=\text { high } \\
\text { and } 4=\text { very high }\end{array}$ & {$[2-9]$} \\
\hline Q.1.1 & $\begin{array}{l}\text { Among different actors, indicate the main } \\
\text { responsible for each of these threats. }\end{array}$ & $0=$ No, $1=$ Yes & \\
\hline Q.2 & $\begin{array}{l}\text { Several reasons for local people to be involved } \\
\text { with practices that threaten conservation }\end{array}$ & $\begin{array}{l}2=\text { strongly agree, } 1=\text { agree, } 0=\text { undecided, } \\
-1=\text { disagree and }-2=\text { strongly disagree }\end{array}$ & {$[2,8,10-13]$} \\
\hline Q.3 & $\begin{array}{l}\text { Put the current compensation measures in } \\
\text { order of importance to the local population }\end{array}$ & $6=$ most important to $1=$ least important & \\
\hline Q.3.1 & $\begin{array}{l}\text { Limitations with the way that current } \\
\text { compensation measures are being delivered }\end{array}$ & $\begin{array}{l}2=\text { strongly agree, } 1=\text { agree, } 0=\text { undecided, } \\
-1=\text { disagree and }-2=\text { strongly disagree }\end{array}$ & {$[2,7,14]$} \\
\hline Q.4 & $\begin{array}{l}\text { What will be the effectiveness of each new } \\
\text { measures below in order to promote the } \\
\text { adoption of conservation-friendly practices }\end{array}$ & $\begin{array}{l}2=\text { very positive, } 1=\text { positive, } 0=\text { no effect; } \\
-1=\text { negative and }-2=\text { very negative }\end{array}$ & [2] \\
\hline Q.4.1 & $\begin{array}{l}\text { Level of improvement with adoption of new } \\
\text { measures }\end{array}$ & $\begin{array}{l}4=76-100 \%, 3=51-75 \%, 2=26-50 \%, 1=1 \\
-25 \% \text { and } 0=0 \%\end{array}$ & Authors \\
\hline Q.4.2 & $\begin{array}{l}\text { Level of improvement in people behaviours and } \\
\text { motivation for conservation }\end{array}$ & $\begin{array}{l}4=\text { very high, } 3=\text { high, } 2=\text { Moderate, } 2=\text { low } \\
\text { and } 0=\text { Null }\end{array}$ & \\
\hline
\end{tabular}

or still work in Mozambique in conservation-related activities, irrespective of being Mozambican citizens; (2) have substantial knowledge about policies and laws that govern protected areas in Mozambique; and (3) know the current management state of the NNR including threats, compensation schemes and the role of all actors involved in conservation. The socio-demographic profile of surveyed

Table 4

Post-hoc cellwise tests between clusters of the degree of threat that each of the existing problems in the NNR represents (Q.1), and reasons for local people engagement in threatening practices $(\mathrm{Q} .2)$.

\begin{tabular}{|c|c|c|c|c|c|}
\hline & & & \multicolumn{3}{|l|}{ Q.1 } \\
\hline & & & N1 & N2 & N3 \\
\hline \multirow[t]{25}{*}{ Q.2 } & N1 & Count & 7 & 0 & 2 \\
\hline & & Expected Count & 4.3 & 2.5 & 2.3 \\
\hline & & \% within Ward Method & $77.8 \%$ & $0.0 \%$ & $22.2 \%$ \\
\hline & & Adjusted Residual & 2.0 & -2.0 & -0.2 \\
\hline & & $\mathrm{P}\left(\mathrm{Z}_{\mathrm{ij}}\right)$ & 0.0450 & 0.0446 & 0.8077 \\
\hline & $\mathrm{N} 2$ & Count & 0 & 5 & 3 \\
\hline & & Expected Count & 3.8 & 2.2 & 2.0 \\
\hline & & $\%$ within Ward Method & $0.0 \%$ & $62.5 \%$ & $37.5 \%$ \\
\hline & & Adjusted Residual & -2.9 & 2.4 & 0.8 \\
\hline & & $P\left(Z_{i j}\right)$ & 0.0038 & 0.0155 & 0.3975 \\
\hline & N3 & Count & 12 & 8 & 6 \\
\hline & & Expected Count & 12.3 & 7.1 & 6.6 \\
\hline & & $\%$ within Ward Method & $46.2 \%$ & $30.8 \%$ & $23.1 \%$ \\
\hline & & Adjusted Residual & -0.2 & 0.6 & -0.4 \\
\hline & & $P\left(Z_{i j}\right)$ & 0.8750 & 0.5814 & 0.7015 \\
\hline & N4 & Count & 1 & 1 & 2 \\
\hline & & Expected Count & 1.9 & 1.1 & 1.0 \\
\hline & & $\%$ within Ward Method & $25.0 \%$ & $25.0 \%$ & $50.0 \%$ \\
\hline & & Adjusted Residual & -0.9 & -0.1 & 1.2 \\
\hline & & $P\left(Z_{i j}\right)$ & 0.3542 & 0.9156 & 0.2419 \\
\hline & N5 & Count & 6 & 1 & 1 \\
\hline & & Expected Count & 3.8 & 2.2 & 2.0 \\
\hline & & $\%$ within Ward Method & $75.0 \%$ & $12.5 \%$ & $12.5 \%$ \\
\hline & & Adjusted Residual & 1.7 & -1.0 & -0.9 \\
\hline & & $P\left(Z_{i j}\right)$ & 0.0893 & 0.3102 & 0.3629 \\
\hline
\end{tabular}


Table 5

Post-hoc cellwise tests between clusters of the degree of threat that each of the existing problems in the NNR represents (Q.1) and compensation measures currently in place at the reserve (Q.3).

\begin{tabular}{|c|c|c|c|c|c|}
\hline & & & \multicolumn{3}{|l|}{ Q.1 } \\
\hline & & & N1 & $\mathrm{N} 2$ & N3 \\
\hline \multirow[t]{15}{*}{ Q.3 } & N1 & Count & 26 & 0 & 0 \\
\hline & & Expected Count & 12.3 & 7.1 & 6.6 \\
\hline & & \% within Ward Method & $100.0 \%$ & $0.0 \%$ & $0.0 \%$ \\
\hline & & Adjusted Residual & 7.4 & -4.3 & -4.1 \\
\hline & & $\mathrm{P}(\mathrm{Zij})$ & 0.0000 & 0.0000 & 0.0000 \\
\hline & N2 & Count & 0 & 15 & 0 \\
\hline & & Expected Count & 7.1 & 4.1 & 3.8 \\
\hline & & \% within Ward Method & $0.0 \%$ & $100.0 \%$ & $0.0 \%$ \\
\hline & & Adjusted Residual & -4.3 & 7.4 & -2.7 \\
\hline & & $\mathrm{P}(\mathrm{Zij})$ & 0.0000 & 0.0000 & 0.0080 \\
\hline & N3 & Count & 0 & 0 & 14 \\
\hline & & Expected Count & 6.6 & 3.8 & 3.6 \\
\hline & & $\%$ within Ward Method & $0.0 \%$ & $0.0 \%$ & $100.0 \%$ \\
\hline & & Adjusted Residual & -4.1 & -2.7 & 7.4 \\
\hline & & $\mathrm{P}(\mathrm{Zij})$ & 0.0000 & 0.0080 & 0.0000 \\
\hline
\end{tabular}

\section{Table 6}

Post-hoc cellwise tests between clusters of the degree of threat that each of the existing problems in the NNR represents for conservation and level of improvement of different ecosystem services, after the implementation of new measures.

\begin{tabular}{|c|c|c|c|c|c|}
\hline & & & \multicolumn{3}{|l|}{ Q.4.1 } \\
\hline & & & $\mathrm{C} 1$ & $\mathrm{C} 2$ & $\mathrm{C} 3$ \\
\hline \multirow[t]{15}{*}{ Q.1 } & $\mathrm{C} 1$ & Count & 20 & 0 & 0 \\
\hline & & Expected Count & 9.5 & 5.5 & 5.1 \\
\hline & & $\%$ within Ward Method & $100.0 \%$ & $0.0 \%$ & $0.0 \%$ \\
\hline & & Adjusted Residual & 5.9 & -3.4 & -3.3 \\
\hline & & $P(Z i j)$ & 0.0000 & 0.0006 & 0.0011 \\
\hline & $\mathrm{C} 2$ & Count & 0 & 8 & 5 \\
\hline & & Expected Count & 6.1 & 3.5 & 3.3 \\
\hline & & $\%$ within Ward Method & $0.0 \%$ & $61.5 \%$ & $38.5 \%$ \\
\hline & & Adjusted Residual & -3.9 & 3.2 & 1.2 \\
\hline & & $\mathrm{P}(\mathrm{Zij})$ & 0.0001 & 0.0015 & 0.2179 \\
\hline & C3 & Count & 6 & 7 & 9 \\
\hline & & Expected Count & 10.4 & 6.0 & 5.6 \\
\hline & & $\%$ within Ward Method & $27.3 \%$ & $31.8 \%$ & $40.9 \%$ \\
\hline & & Adjusted Residual & -2.4 & 0.6 & 2.1 \\
\hline & & $\mathrm{P}(\mathrm{Zij})$ & 0.0153 & 0.5366 & 0.0317 \\
\hline
\end{tabular}

experts is presented in Table 2. The questionnaire used to generate the dataset is presented in Appendix A. An online and self-administrated survey was presented to experts engaged in conservation in the NNR, in both Portuguese (Mozambican National Language) and English. The survey's main aim was to collect experts' perceptions and opinions on conservation-related issues, namely: (i) main practices threatening conservation in the NNR and those responsible for each practice; (ii) the reasons for local people's involvement with practices threatening conservation; (iii) effectiveness and limitations of current compensation measures to engage local people in conservation; and (iv) new measures that can be proposed to enhance conservation on the reserve. The survey also included a section on the socio-economic profile of respondents. The response rate was $68.76 \%$, with two non-valid responses, that were dropped from the analysis.

The survey was coded in different rating scales depending on the question being analysed, according to the Excel spreadsheet and Table 3. Most of the questions were taken from the literature and 
Table 7

Post-hoc cellwise tests between clusters of reasons for local people being involved with practices that threaten conservation, (Q.2) and compensation measures currently in place at the reserve (Q.3).

\begin{tabular}{|c|c|c|c|c|c|}
\hline & & & \multicolumn{3}{|l|}{ Q.3 } \\
\hline & & & N1 & N2 & N3 \\
\hline \multirow[t]{25}{*}{ Q.2 } & N1 & Count & 7 & 0 & 2 \\
\hline & & Expected Count & 4.3 & 2.5 & 2.3 \\
\hline & & $\%$ within Ward Method & $77.8 \%$ & $0.0 \%$ & $22.2 \%$ \\
\hline & & Adjusted Residual & 2.0 & -2.0 & -0.2 \\
\hline & & $\mathrm{P}(\mathrm{Zij})$ & 0.0450 & 0.0446 & 0.8077 \\
\hline & N2 & Count & 0 & 5 & 3 \\
\hline & & Expected Count & 3.8 & 2.2 & 2.0 \\
\hline & & $\%$ within Ward Method & $0.0 \%$ & $62.5 \%$ & $37.5 \%$ \\
\hline & & Adjusted Residual & -2.9 & 2.4 & 0.8 \\
\hline & & $\mathrm{P}(\mathrm{Zij})$ & 0.0038 & 0.0155 & 0.3975 \\
\hline & N3 & Count & 12 & 8 & 6 \\
\hline & & Expected Count & 12.3 & 7.1 & 6.6 \\
\hline & & $\%$ within Ward Method & $46.2 \%$ & $30.8 \%$ & $23.1 \%$ \\
\hline & & Adjusted Residual & -0.2 & 0.6 & -0.4 \\
\hline & & $\mathrm{P}(\mathrm{Zij})$ & 0.8750 & 0.5814 & 0.7015 \\
\hline & N4 & Count & 1 & 1 & 2 \\
\hline & & Expected Count & 1.9 & 1.1 & 1.0 \\
\hline & & $\%$ within Ward Method & $25.0 \%$ & $25.0 \%$ & $50.0 \%$ \\
\hline & & Adjusted Residual & -0.9 & -0.1 & 1.2 \\
\hline & & $\mathrm{P}(\mathrm{Zij})$ & 0.3542 & 0.9156 & 0.2419 \\
\hline & N5 & Count & 6 & 1 & 1 \\
\hline & & Expected Count & 3.8 & 2.2 & 2.0 \\
\hline & & \% within Ward Method & $75.0 \%$ & $12.5 \%$ & $12.5 \%$ \\
\hline & & Adjusted Residual & 1.7 & -1.0 & -0.9 \\
\hline & & $\mathrm{P}(\mathrm{Zij})$ & 0.0893 & 0.3102 & 0.3629 \\
\hline
\end{tabular}

\section{Table 8}

Post-hoc cellwise tests between compensation measures that are currently in place at the reserve (Q.3) and level of improvement of different ecosystem services, after the implementation of new measures (Q.4.1).

\begin{tabular}{|c|c|c|c|c|c|}
\hline & & & \multicolumn{3}{|l|}{ Q.4.1 } \\
\hline & & & $\mathrm{N} 1$ & N2 & N3 \\
\hline \multirow[t]{15}{*}{ Q.3 } & N1 & Count & 20 & 0 & 0 \\
\hline & & Expected Count & 9.5 & 5.5 & 5.1 \\
\hline & & $\%$ within Ward Method & $100.0 \%$ & $0.0 \%$ & $0.0 \%$ \\
\hline & & Adjusted Residual & 5.9 & -3.4 & -3.3 \\
\hline & & $\mathrm{P}(\mathrm{Zij})$ & 0.000 & 0.001 & 0.001 \\
\hline & N2 & Count & 0 & 8 & 5 \\
\hline & & Expected Count & 6.1 & 3.5 & 3.3 \\
\hline & & $\%$ within Ward Method & $0.0 \%$ & $61.5 \%$ & $38.5 \%$ \\
\hline & & Adjusted Residual & -3.9 & 3.2 & 1.2 \\
\hline & & $\mathrm{P}(\mathrm{Zij})$ & 0.000 & 0.002 & 0.218 \\
\hline & N3 & Count & 6 & 7 & 9 \\
\hline & & Expected Count & 10.4 & 6.0 & 5.6 \\
\hline & & $\%$ within Ward Method & $27.3 \%$ & $31.8 \%$ & $40.9 \%$ \\
\hline & & Adjusted Residual & -2.4 & 0.6 & 2.1 \\
\hline & & $P(Z i j)$ & 0.015 & 0.537 & 0.032 \\
\hline
\end{tabular}

brainstorming with a selected group of experts who have deep knowledge about conservation in NNR and other related conservation areas in the country. More detailed information about all the topics is available in Table 3 [1].

Respondents' ratings were first analysed through principal components for dimension reduction and subsequently to detect clusters structures. To understand whether there was any relationship 
Table 9

Post-hoc cellwise tests between the level of education and cluster of level of improvement of different attributes, after the implementation of new measures.

\begin{tabular}{|c|c|c|c|c|c|}
\hline & & & \multicolumn{3}{|l|}{ Education } \\
\hline & & & Lower \& Intermediate & Upper Secondary School & Higher Education \\
\hline \multirow[t]{15}{*}{ Q.4.1 } & \multirow[t]{5}{*}{ N1 } & Count & 5 & 1 & 14 \\
\hline & & Expected Count & 5.5 & 2.2 & 12.4 \\
\hline & & \% within Ward Method & $25.0 \%$ & $5.0 \%$ & $70.0 \%$ \\
\hline & & Adjusted Residual & -0.3 & -1.1 & 0.9 \\
\hline & & $P(Z i j)$ & 0.7748 & 0.2880 & 0.3451 \\
\hline & \multirow[t]{5}{*}{ N2 } & Count & 4 & 5 & 4 \\
\hline & & Expected Count & 3.5 & 1.4 & 8.0 \\
\hline & & $\%$ within Ward Method & $30.8 \%$ & $38.5 \%$ & $30.8 \%$ \\
\hline & & Adjusted Residual & 0.3 & 3.6 & -2.6 \\
\hline & & $P(Z i j)$ & 0.7460 & 0.0003 & 0.0084 \\
\hline & \multirow[t]{5}{*}{ N3 } & Count & 6 & 0 & 16 \\
\hline & & Expected Count & 6.0 & 2.4 & 13.6 \\
\hline & & $\%$ within Ward Method & $27.3 \%$ & $0.0 \%$ & $72.7 \%$ \\
\hline & & Adjusted Residual & 0.0 & -2.1 & 1.4 \\
\hline & & $P(Z i j)$ & 1.0000 & 0.0341 & 0.1739 \\
\hline
\end{tabular}

between different views of respondents in all major themes, a crosstabulation between clusters was tested based on Fisher's Exact test and Asymptotic Person's Chi-Square [15,16]. When a significant relationship was detected, a post-hoc cellwise test (goodness-of-fit) was performed in order to find those attributes most significant for the association, and spell out the meaning of those relationships, based on the adjusted standardized residuals and adjusted alpha $(\alpha)$ [17-19]. The same technique was applied between clusters of major themes and socio-economic profile of respondents to understand whether their socio-economic background can also explain the points of views of respondents concerning major themes. Data from the post-hoc test is available in Tables 4-9 For more detailed information about the methodology see Mbanze et al. (2019) [1].

\section{Acknowledgements}

The authors acknowledge all institutions and individuals who directly and indirectly supported data acquisition. We especially acknowledge all experts who spend their time to fill out our questionnaire and all district entities and workers who supported our workshop. We also acknowledge the following organizations: World Wildlife Fund (WWF)/Russell E. Training Education for Nature Program Fund in Washington, DC, provided funds for workshop (grant contract \#RF37); Fundação para Ciência e Tecnologia (FCT) of Portugal, who provides the research fellowship to the first author (Ref $n^{0} \mathrm{SFRH} / \mathrm{BD} /$ 113955/2015); Colleen Beeg and Agostinho Jorge from Niassa Carnivorous Project who shared important ideas to improve the questionnaire.

\section{Conflict of Interest}

The authors declare that they have no known competing financial interests or personal relationships that could appeared to influence the work reported in this paper.

\section{Appendix A. Supplementary data}

Supplementary data to this article can be found online at https://doi.org/10.1016/j.dib.2019.105080.

\section{References}

[1] A. Mbanze, N. Ribeiro, C. Da Silva, J. Lima, An expert-based approach to assess the potential for local people engagement in nature conservation: the case study of the Niassa National Reserve in Mozambique, J. Nat. Conserv. (2019) 1-10, https:// doi.org/10.1016/j.jnc.2019.125759. 
[2] NCP (2015), Niassa carnivore project - annual report. Niassa carnivore project.

[3] A.A. Jorge, A.B.I.T. Vanak, M. Thaker, C. Begg, R.O.B. Slotow, Costs and benefits of the presence of leopards to the sporthunting industry and local communities in Niassa National reserve, Mozambique 27 (2013) 832-843, https://doi.org/ $10.1111 /$ cobi.12082.

[4] N.S. Ribeiro, H.H. Shugart, R. Washington-Allen, The effects of fire and elephants on species composition and structure of the Niassa Reserve, northern Mozambique, For. Ecol. Manag. 255 (2008) 1626-1636, https://doi.org/10.1016/j.foreco.2007. 11.033.

[5] A. Martins, Avaliação Da Estrutura Fitossociológica Dos Ecossistemas De Dambos Na Reserva Nacional Do Niassa (Rnn) Ecossistemas De Dambos Na Reserva Nacional, Universidade Lúrio, 2015.

[6] K.M. Booth, R. Vernon, Dunham, Elephant poaching in Niassa Reserve, Mozambique: population impact revealed by combined survey trends for live elephants and carcasses, Oryx (2014) 1-10, https://doi.org/10.1017/S0030605314000568.

[7] Q. Muarapaz, Avaliação da eficácia de conservação e gestão de recursos naturais usando o METT: Caso de estudo da Reserva Nacional do Niassa, 2016, p. 102.

[8] MICOA, Fifth National Report on Implementation of the Convention on Biological Diversity in MOZAMBIQUE, Maputo, 2014.

[9] NCP (2016), Niassa carnivore project - annual report. Niassa carnivores project. NCP.

[10] D.W. Aheto, S. Kankam, I. Okyere, E. Mensah, A. Osman, F.E. Jonah, J.C. Mensah, Community-based mangrove forest management: implications for local livelihoods and coastal resource conservation along the Volta estuary catchment area of Ghana, Ocean Coast Manag. 127 (2016) 43-54, https://doi.org/10.1016/j.ocecoaman.2016.04.006.

[11] J. Bluwstein, J.F. Lund, Territoriality by conservation in the selous-Niassa corridor in Tanzania, World Dev. xx (2016), https://doi.org/10.1016/j.worlddev.2016.09.010.

[12] F. Mombo, L. Lusambo, S. Speelman, J. Buysse, P. Munishi, G. van Huylenbroeck, Scope for introducing payments for ecosystem services as a strategy to reduce deforestation in the Kilombero wetlands catchment area, For. Policy Econ. 38 (2014) 81-89, https://doi.org/10.1016/j.forpol.2013.04.004.

[13] N. Giva, Parks with People? Swedish University of Agricultural Science, 2016. https://pub.epsilon.slu.se/13740/1/giva_n_ 161024.pdf.

[14] M. Tembo, E. Soto, C. Coelho, Impacto de Corte de Árvores para as Actividades de Agricultura e Pesqueira sobre a Floresta Ribeirinha ao Longo do Rio Lugenda e seus Afluentes, na Reserva Nacional do Niassa, 2015.

[15] Y.H. Chan, Biostatistics 103: qualitative data - tests of independence, Singap. Med. J. 44 (2003) 498-503.

[16] C.R. Mehta, N.R. Patel, IBM SPSS Exact Tests, 2011, 2011, pp. 1-236.

[17] M.A. García-Pérez, V.V. Núñez-Antón, Cellwise residual analysis in two-way contingency tables, Educ. Psychol. Meas. 63 (2003) 825-839, https://doi.org/10.1177/0013164403251280.

[18] T.M. Beasley, R.E. Schumacker, Multiple regression approach to analyzing contingency tables: post hoc and planned comparison procedures, J. Exp. Educ. 64 (1995) 79-93, https://doi.org/10.1080/00220973.1995.9943797.

[19] D. Sharpe, Your Chi-square test is statistically significant: now what? - practical assessment, Res. Eval. 20 (2015), https:// doi.org/10.2307/3001616. 